\title{
First record of Hydrosmilodon primanus (Eaton) (Ephemeroptera, Leptophlebiidae) from South America
}

\author{
Luis Gonzalo Salinas ${ }^{1,2,5}$, Ralph Wills Flowers ${ }^{3}$ \& Lucimar Gomes Dias $^{4}$
}

${ }^{1}$ Laboratório de Sistemática e Ecologia de Insetos, Programa de Pós-graduação em Biodiversidade Tropical, Departamento de Ciências Agrárias e Biológicas, Centro Universitário Norte do Espírito Santo,

Universidade Federal do Espírito Santo - UFES, Rod. BR 101 Norte, Km 60, Bairro Litorâneo, CEP 29932-540, São Mateus, ES, Brasil

${ }^{2}$ Programa de Estudantes-Convênio de Pós-graduação - PEC-PG, CNPq

${ }^{3}$ Center for Biological Control, FL 32307, Tallahassee, Florida, USA. http://www.famu.edu/

${ }^{4}$ Departamento de Ciencias Biológicas, Facultad de Ciencias Exactas y Naturales, Universidad de Caldas, Calle 65, 26-10, A.A 275, Manizales, Caldas, Colombia. http://www.ucaldas.edu.co/

${ }^{5}$ Corresponding author: Luis Gonzalo Salinas, e-mail: biobaetodes@gmail.com

SALINAS, L.G., FLOWERS, R.W. \& DIAS, L.G. First record of Hydrosmilodon primanus (Eaton) (Ephemeroptera, Leptophlebiidae) from South America. Biota Neotrop. (13)1: http://www.biotaneotropica. org.br/v13n1/en/abstract?short-communication+bn01513012013

Abstract: In this paper the first record of Hydrosmilodon primanus (Eaton, 1892) from South America is presented. The record of the species is based on nymphs collected in San Sebastián de Mariquita city, Tolima department, Colombia.

Keywords: Hermanella, mayfly, Colombia.

SALINAS, L.G., FLOWERS, R.W. \& DIAS, L.G. Primer registro de Hydrosmilodon primanus (Eaton) (Ephemeroptera, Leptophlebiidae) para Sur América. Biota Neotrop. (13)1: http://www.biotaneotropica.org. br/v13n1/pt/abstract?short-communication+bn01513012013

Resumen: En este trabajo se presenta por primera vez el registro de la especie Hydrosmilodon primanus (Eaton, 1892) para Sur América. El registro de la especie es basado en ninfas colectadas en el municipio de San Sebastián de Mariquita, departamento del Tolima, Colombia.

Palabras clave: Hermanella, efimera, Colombia. 


\section{Introduction}

The Hermanella complex of the Leptophlebiidae is a group of distinctive mayflies distributed primarily in the neotropics and also extending into the Nearctic region (Domínguez \& Flowers 1989). Nymphs are distinguished by possess large maxillary palpi attached at the posterior portion of maxilla, with long and fine setae on the third segment in parallel rows; an expanded labrum nearly as wide as the head capsule; also prominent anterolateral areas of the clipeus, rectangular shape of the mandibles, often with sharp anterolateral angle; and broad and rectangular superlinguae. Moreover, the abdominal postero-lateral spines are present on segments 8 and 9, rarely also 7 . Genera described in this group are Hermanella (Needham \& Murphy, 1924), Leentvaaria (Demoulin, 1966), Traverella (Edmunds, 1948), Hylister (Domínguez \& Flowers, 1989), Needhamella (Domínguez \& Flowers, 1989), Hydrosmilodon (Flowers \& Domínguez, 1992), Paramaka (Savage \& Domínguez, 1992), and Hydrosmastodon (Polegatto \& Batista, 2007).

The genus Hydrosmilodon Domínguez \& Flowers, 1992 (Ephemeroptera: Leptophlebiidae) was described based on the adult of the type species Thraulus primanus Eaton, 1892 found in Mexico. They also described the new species Hydrosmilodon saltensis Flowers \& Domínguez, 1992, based on the male imago and mature nymph found in Argentina. In the same paper, these authors recorded $H$. primanus from Panama, Costa Rica, and Honduras (Flowers \& Domínguez 1992), broadening the range of the species. Currently, two species of the genus are documented from South America: Hydrosmilodon gilliesae Thomas \& Boutonnet, 2004 and Hydrosmilodon saltensis. The first record of the genus from Colombia was during studies in Catugado and Totunendo rivers in the Chocó department, where the species were not determined (Casas-Cordoba et al. 2006).

\section{Materials and Methods}

Specimens were collected in the stream "El Chondo" $5^{\circ} 11$ ' 31 " N and 74 53' 59' W, located in San Sebastián de Mariquita (Tolima), in the Cordillera Central of Colombia. Species were identified using the key of Domínguez et al. (2006) and the original description made by Flowers \& Domínguez (1992). The individuals collected are deposited in the Entomological Collections of the Biology Program of the Universidad de Caldas (CEBUC) in Manizales, Colombia.

\section{Results and Discussion}

In this study, $H$. primanus initially recorded from Central America (Panama, Honduras and Costa Rica) (Flowers \& Domínguez 1992) is recorded for the first time from South America based on 10 nymphs collected in El Chondo stream, Tolima department, Colombia (Figure 1). The altitude found in El Chondo is similar to the registered in some streams in Costa Rica (479 m.a.s.l. and 470 m.a.s.1., respectively). The nymphs collected in both sites were found in rocky substrate.

During identification of Hydrosmilodon nymphs, it could be noted that they can be confused with nymphs of two genera of the Hermanella group (Leentvaaria Demoulin, 1966 and Hydromastodon Polegatto \& Batista, 2007). These genera possess slender gills and well developed maxillary tooth (Polegatto \& Batista, 2007). However, the genus Hydrosmilodon can be separated from these two genera, mainly by the size of apical denticle of the tarsal claw and the anterior margin of labrum distinctly emarginated.

Nymphs of $H$. primanus found in Colombia possess mandibles with setae confined to base, basal segment of labial palpi with welldefined dark markings and the anterior margin of labrum distinctly emarginated. These characters are the same used for Flower \& Domínguez (1992) for the identification and determination of the specie.

With this paper we present the first report of this species in South America and the broadening the distribution of the genera in Colombia.

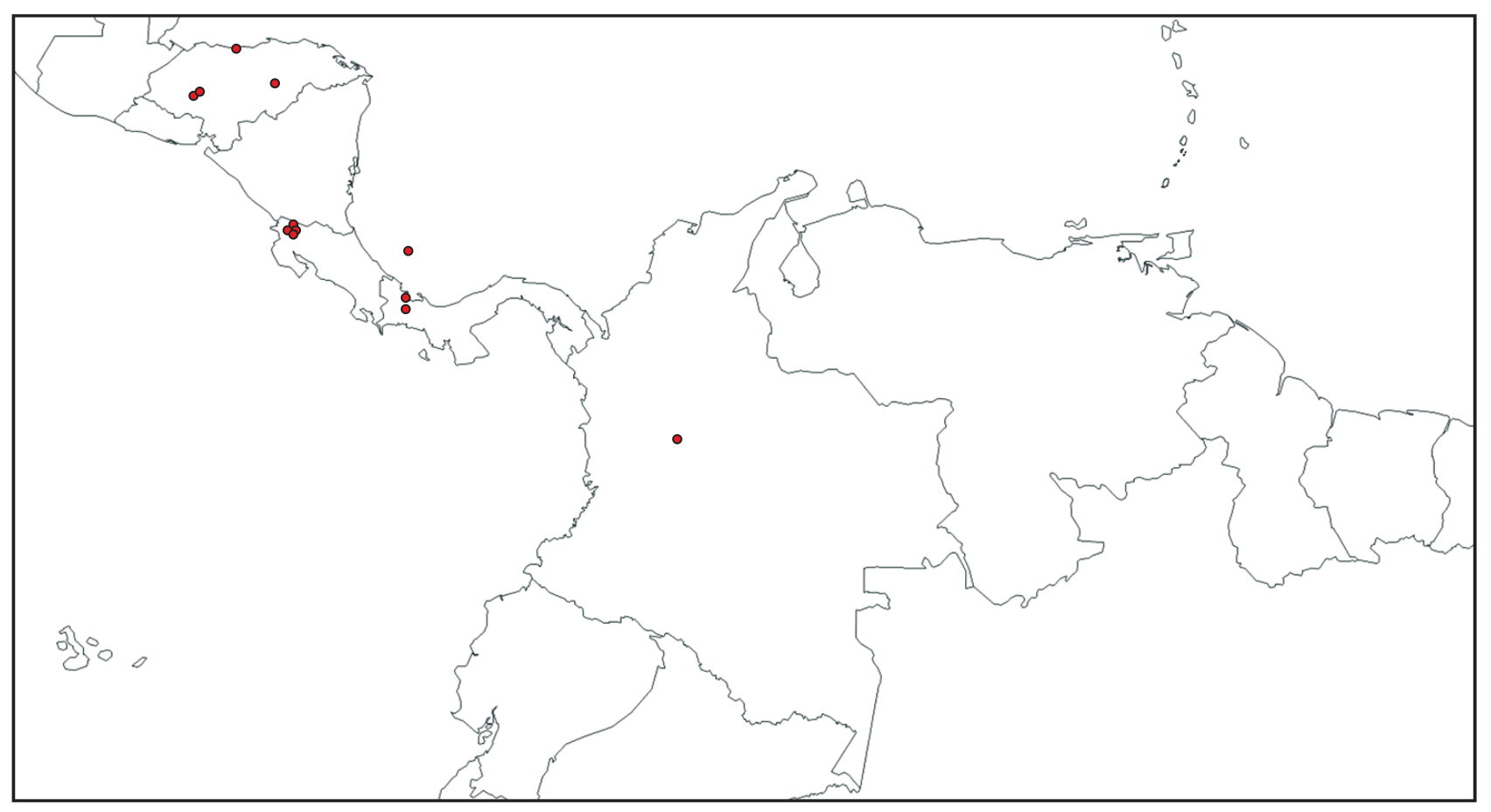

Figure 1. Distribution of Hydrosmilodon primanus on America. 


\section{Acknowledgements}

The authors acknowledge to Universidad de Caldas who facilitated its installations for the samples analysis. Luis Salinas acknowledge to Natalia Hurtado for her helpful review of the manuscript.

\section{References}

CASAS-CORDOBA, L., CORDOBA-ARAGON, K., ASPRILLAMURILLO, S. \& MOSQUERA, Z. 2006. Composición y distribución del orden Efemeróptera en los ríos Tutunendo y Catugadó. Quibdó - Chocó - Colombia. In VII Seminario Colombiano de Limnología y I Reunión de Ríos y Humedales Neotropicales. Ibagué, p.92-97.
DOMÍNGUEZ, E. \& FLOWERS, R.W. 1989. A revision of Hermanella and related genera (Ephemeroptera: Leptophlebiidae: Atalophlebiinae) from subtropical South America. Ann Entomol Soc Am. 82:555-573.

DOMÍNGUEZ, E., MOLINERI, C., PESCADOR, M.L., HUBBARD, M.D. \& NIETO, C. 2006. Ephemeroptera of South America. In Aquatic Biodiversity of Latin America (J. Adis, J.R. Arias, G. Rueda-Delgado \& K.M. Wantzen, eds.). Pensoft, Moscow-Sofia, v.2, p.1-646.

FLOWERS, R.W. \& DOMÍNGUEZ, E. 1992. New genus of Leptophlebiidae (Ephemeroptera) from Central and South America. Ann Entomol Soc Am. 85(6):655-661.

POLEGATTO, C.M \& BATISTA, J.D. 2007. Hydromastodon sallesi, new genus and new species of Atalophlebiinae (Insecta: Ephemeroptera: Leptophlebiidae) from West and North of Brazil, and notes on systematics of Hermanella group. Zootaxa 1619:53-60. 